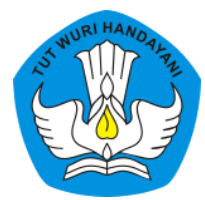

Page: 801-820

\title{
PENGGUNAAN MEDIA GOOGLE MEET DALAM MENINGKATKAN MOTIVASI BELAJAR PADA MASA PANDEMI COVID-19
}

\author{
Ida Sri Astutik \\ Sekolah Dasar Negeri Minggiran I Kabupaten Kediri, Jawa Timur, Indonesia \\ Contributor Email: ida.sriastutik82gmail.com
}

Received: Feb 15, 2021

Accepted: Oct 7, 2021

Published: Nov 30, 2021

Article Url: https:/ / ojsdikdas.kemdikbud.go.id/index.php/didaktika/article/view/368

\begin{abstract}
The purpose of this study is to describe the empowerment of learning media google meet as one of the remote learning tools that can increase the motivation of students' learning during the covid-19 pandemic. This research is a descriptive quarative research. Data collection techniques are conducted with observations, interviews, and questionnaires on the use of Google Meet media. This research was conducted in grade $V$ of SDN Minggiran I, Kediri Regency. Data analysis techniques are performed with Milles $\mathcal{E}$ Huberman interactive analysis. The results showed that the application of Google Meet media in distance learning activities during the covid-19 pandemic had a positive impact on students' learning motivation. This shows that Google Meet media provides benefits for teachers and students because of the teaching and learning process that can interact directly so as to make online learning more practical and effective. This direct interaction also increases the involvement and activeness of students during online learning during the Covid-19 pandemic.
\end{abstract}

Keywords: Distance Learning; Google Meet; Pandemic Covid-19. 


\begin{abstract}
Abstrak
Tujuan penelitian ini adalah mendeskripsikan pemberdayaan media pembelajaran google meet sabagai salah satu perangkat pembelajaran jarak jauh yang dapat meningkatkan motivasi belajar siswa pada masa masa pandemi Covid-19. Penelitian ini merupakan penelitian kualiatif deskriptif. Teknik pengumpulan data dilakukan dengan observasi, wawancara, dan angket terhadap pengounaan media Google Meet. Penelitian ini dilakukan di kelas V SDN Minggiran I Kabupaten Kediri. Teknik analisis data dilakukan dengan analisis interaktif Milles $\mathcal{E}$ Huberman. Hasil penelitian menunjukkan bahwa penerapan media Google Meet dalam kegiatan pembelajaran jarak jauh selama pandemi Covid-19 memberi dampak positif terhadap motivasi belajar peserta didik. Hal ini menunjukkan bahwa media Google Meet memberikan manfaat bagi guru dan peserta didik karena proses belajar mengajar yang dapat berinteraksi secara langsung sehingga membuat pembelajaran daring menjadi lebih praktis dan efektif. Interaksi secara langsung ini juga meningkatkan keterlibatan dan keaktifan peserta didik selama pembelajaran daring di masa pandemi Covid-19.
\end{abstract}

Kata Kunci: Google Meet; Pandemi Covid-19; Pembelajaran Jarak Jauh.

\title{
A. Pendahuluan
}

Pandemi Covid-19 telah menggetarkan seluruh pelosok negeri, begitupun roda pendidikan ikut terkena dampaknya. Paradigma pendidikan pun harus segera berbenah agar tidak ikut tenggelam dalam gelombang dashyatpandemi Covid-19. Pembelajaran jarak jauh (PJJ), belajar dari rumah (BDR), blended learning, e-learning, merupakan serentetan program pemerintah melalui Kementerian Pendidikan dan Kebudayaan Riset dan Teknologi (Kemdikbudristek) sebagai banteng melawan badai pandemi agar dunia pendidikan tidak ikut tenggelam. Pandemi memberikan dampak kepada semua pemangku kepentingan (stakeholder) termasuk guru dan orangtua. Pandemi memberikan perubahan besar terhadap system belajar dan pembelajaran, khususnya strategi pembelajaran di sekolah secara langsung menjadi strategi pembelajaran di sekolah secara tidak langsung. Dampak pandemi, kegiatan pembelajaran di sekolah secara langsung berubah menjadi strategi pembelajaran tidak langsung melalui model PJJ.

Pemerintah melalui Kemdikbudristektelah melahirkan berbagai program baru dalam sistem pendidikan untuk kelangsungan proses 
belajar siswa di masa pandemi. Sederet kebijakan dikeluarkan untuk menunjang kelangsunganproses belajar mengajar guru bersama siswa di sekolah, sesuai visi Indonesia yaitu "SDM Unggul, Indonesia Maju". Kemdikbudristek telah menggulirkan aturan baru melalui Permendikbud Nomor 4 Tahun 2020 tentang Pelaksanaan Kebijakan Pendidikan dalam Masa Darurat Penyebaran Corona Virus Disease (Covid-19). Dua poin penting isi dari Permendikbud Nomor 4 Tahun 2020 bahwa kegiatan belajar dari rumah melalui pembelajaran daring/ jarak jauh dilaksanakan untuk memberikan pengalaman belajar yang bermakna serta difokuskan pada pendidikan kecakapan hidup (life skill). Menurut Ausubel, belajar yang bermakna adalah pembelajaran yang dilaksanakan oleh guru dengan mengaitkan antara pengetahuan yang sudah dimiliki peserta didik dengan sumber belajar yang disampaikan guru; guru menyusun sumber belajar sedemikian rupa sehingga menjadikan pembelajaran benar-benar bermakna bagi peserta didik. Dalam pembelajaran siswadapat menngaplikasikan lebih banyak panca inderanya, tidak sekadar mendengar ataumenyimak saja tetapi juga mempraktikkan secara langsung. Belajar bermakna adalah pendekatan pengelolaan sistem belajar mengajar melalui metode belajar aktif menuju belajar mandiri. Pengalaman belajar hasil kegiatan pembelajaran yang bermakna oleh guru sangat ditentukan oleh bagaimana guru mengemas rencana pembelajaran itu serta lingkungan belajar siswa.

Selama pandemi, strategi pembelajaran bermakna sangat dibutuhkan, utamanya guru dalam menciptakan inovasi pembelajaran dan bagaimana strategi menyampaikannya kepada peserta didik, agar peserta didik tetap semangat belajar dari rumah (BDR), sehingga memberikan hasil belajar yang otentik dan berdampak positif pada peserta didik. Inovasi pembelajaran matematika sangat dibutuhkan agar peserta didik lebih mudah memahami materi pembelajaran serta mempermudah orangtua dalam mendampingi putra putrinya selama kegiatan BDR. Dewi menyebut bahwa dengan pembelajaran 
daringsiswa memiliki keleluasaan waktu belajar, dapatbelajar kapanpun dan dimanapun (Dewi, 2020).

Pembelajaran jarak jauh yang selama ini dilaksanakan yaitu menggunakan platform media whats app group. Namun, banyak masalah yang muncul karena guru selaku penulis hanya menggunakan media WhatsApp group. Masalah tersebut diantaranya (1) notifikasi tugas sekolah bercampur dengan notifikasi urusan luar sekolah dari orang tua/wali siswa dan (2) siswa tidak semangat belajar karena tidak bertatapan dengan teman sekelas dan guru saat penjelasan materi. Dari sini, bisa diketahui bahwa motivasi belajar siswa saat pembelajaran daring menggunakan WhatsApp group rendah. Padahal, motivasi belajar peserta didik sangat menentukan hasil belajar mereka. Keduanya memiliki korelasi yang positif (Setiawan 2019b). Fitriyani, dkk. menjelaskan lebih lanjut bahwa terdapat delapan indikator motivasi belajar, yaitu konsentrasi, rasa ingin tahu, semangat, kemandirian, kesiapan, antusias atau dorongan,pantang menyerah, dan percaya diri(Fitriyani, Fauzi, and Sari 2020). Keberhasilan pembelajaran dipengaruhi oleh banyak faktor.Penelitian Hasnidar dan Elihami menemukan bahwa harapan pembelajaran yang efektif seringkali tidak terwujud karena beberapa faktor antara lain, peserta didik itu sendiri, materi pelajaran, guru, orang tua, dan strategibelajar mengajar yang disiapkan guru palingtidak guru harus menguasai materi yang diajarkan dan terampil dalam mengajarkan (Hasnidar and Elihami 2020). Namun, pada penelitian ini, penulis akan berfokus pada motivasi belajar peserta didik saja dalam penggunaan platform media yang digunakan selama pembelajaran jarak jauh di masa pandemi Covid-19 yaitu Google Meet.

Uraian di atas menunjukkan bahwa pembelajaran yang efektif seharusnya memungkinkan terjadinya interaksi positif antara guru dengan peserta didik dalam upaya mencapai tujuan pembelajaran. Hal ini tentunya juga dipengaruhi oleh motivasi belajar peserta didik. Pembelajaran akan berlangsung efektif jika peserta didik memiliki motivasi belajar (Emda 2017). Motivasi tidak hanya muncul pada diri peserta didik, tetapi juga ditentukan oleh faktor eksternal lainnya. Emda menjelaskan bahwa motivasi diklasifikasikan menjadi dua yaitu motivasi internal dan eksternal. 
Motivasi instrinsik merupakan keadaan-keadaan yang berasal dari dalam diri peserta didik yang dapat mendorongnya melakukan tindakan belajar, dan motivasi ekstrinsik yang dipengaruhi oleh faktor dari luar peserta didik (Emda 2017). Dengan demikian, keberhasilan belajar akan tercapai apabila pada diri peserta didik terdapat kemauan dan dorongan untuk belajar.Setiawan menemukan bahwa faktor yang memengaruhi motivasi belajar adalah motivasi intrinsik, efikasi diri, determinasi diri, motivasi nilai, dan motivasi karier. Bahkan, penelitian tersebut mengungkap bahwa efikasi diri termasuk komponen penting bagi pelajar dalam menjaga ketekunan selama terlibat pembelajaran untuk meraih prestasi yang diharapkan (Setiawan 2019a). Hal ini menyiratkan makna bahwa guru perlu mendorong peserta didik untuk terbiasa menghadapi tantangan seperti melalui tugas gunamemberi pengalaman agar kemampuan mereka berkembang.

Oleh karena itu, guru selaku penulis merancang pembelajaran jauh menggunakan platform media yang lain yaitu Google Meet. Menurut Nalurita (2021) Google Meet merupakan platform ke dua terpopuler yang digunakan dalam pembelajaran daring merupakan fitur premium dari software Video Conferencing Google. Google Meet lebih mudah digunakan atau user friendly. Hanya dengan membukanya via Google Chrome dan login melalui email sudah dapat digunakan. Dengan hadirnya media Google Meet, pembelajaran jarak jauh yang dilakukan selama pandemi Covid-19 menjadi lebih bervariasi sehingga dapat mengatasi kejenuhan peserta didik yang selama ini hanya menggunakan platform media whats app group. Hal ini tidak lain karena peserta didik dapat berinteraksi langsung bersama guru dan teman sejawatnya pada setiap pertemuan. Oleh karenanya, selain digunakan sebagai platform media belajar dari rumah yang dapat meningkatkan motivasi belajar peserta didik selama pandemi, penulisan artikel ini juga diharapkan dapat memberikan gambaran nyata kepada seluruh penggiat pendidikan utamanya guru sekolah dasar terkait penggunaan platform media Google Meet di kelas lima sekolah dasar.

Penggunaan berbagai macam aplikasi pembelajaran jarak jauh menunjukkan bahwa pandemi Covid-19 telah mempercepat revolusi industri dalam bidang pendidikan. Revolusi industri generai 4.0 ditandai dengan 
semakin meningkatnya konektivitas, interaksi serta perkembangan sistem digital, kecerdasan artifisial, dan virtual (Lase 2019). Oleh karenanya, dampak revolusi industri tersebut sangat nyata terlihat di bidang pendidikan pendidikan utamanya pada masa pandemi Covid-19. Pandemi Covid-19 memaksa seluruh eleman masyarakat melek teknologi, keterampilan masyarakat mengalami percepatan dalam menggunakan teknologi. Masyarakat menjadi lebih mengenal berbagai macam aplikasi yang membantu mereka melaksanakan aktivitas sehari-hari, seperti aktivitas sekolah yang dilakukan oleh guru dan peserta didik. Ghufron menyebut industri 4.0 sebagai fase revolusi teknologi yang mengubah cara beraktifitas manusia dalam skala, ruang lingkup, kompleksitas, dan transformasi dari pengalaman hidup sebelumnya. Manusia bahkan akan hidup dalam ketidakpastian (uncertainty) global, oleh karena itu manusia harus memiliki kemampuan untuk memprediksi masa depan yang berubah sangat cepat. Hal inilah yang sekarang ini terjadi pada masa pandemi Covid-19 (Ghufron 2018). Seluruh aktivitas masyarakat tidak lepas dari teknologi. Meskipun demikian, keefektifan pembelajaran juga sangat bergantung pada guru. Hariri dan Yayuk menyebut bahwa model pembelajaran dapat dijadikan sebagai pola pilihan, artinya guru boleh memilih model pembelajaran yang sesuai dan efisien untuk mencapai tujuan pembelajaran (Hariri and Yayuk 2018). Selain itu, guru juga dituntut untuk bisa memberikan kemudahan bagi para peserta didik dengan pembelajaran yang mudah dipahami dan menyenangkan. Namun, untuk mewujudkannya juga diperlukan komponenkomponen lain untuk mendukung pembelajaran yang efektif (Rohman, Suryawan, and Priyanto 2019). Oleh karena itu, penulis menggambarkan secara nyata terkait penggunaan media Google Meet. Hal ini semata-mata juga menjadi sumbangsih untuk para penggiat pendidikan terkait berbagai kemudahan dan kendala yang dialami penulis selama menggunakan media Google Meet pada pembelajran jarak jauh di masa pandemi Covid-19.

\section{B. Metode}

Metode penelitian ini merupakan penelitian kualiatif deskriptif yang mendeskripsikan kegiatan belajar dari rumah selama pandemi Covid-19 
menggunakan Google Meet. Metode penelitian kualitatif menurut Sugiyono adalah metode penelitian yangdigunakan untuk meneliti pada kondisi obyek yang alamiah dimana peneliti adalah sebagai instrumen kunci (Sugiyono, 2015:9). Penelitian ini dilakukan di SDN Minggiran I Kabupaten Kediri. Subjek penelitian adalah peserta didik kelas $\mathrm{V}$ sekolah dasar. Teknik pengumpulan data yang digunakan yaitu teknik observasi, wawancara, dan angket motivasi belajar. Teknik analisis data menggunakan analisis interaktif Milles \& Huberman yang terdiri dari pengumpulan data, reduksi data, penyajian data, dan penarikan kesimpulan (Milles and Huberman 1992).

\section{Hasil dan Pembahasan}

\section{Hasil}

Platform media pembelajaran daring yang selama ini digunakan hanyalah WhatsApp group, yang mana penjelasan materi dilakukan dengan pengiriman video dan tugas dari guru. Hal tersebut menjadi faktor kejenuhan peserta didik selama belajar dari rumah pada masa pandemi Covid-19. Oleh karenanya, penggunaan platform media yang baru yaitu Google Meeting menjadi variasi media baru bagi guru yang juga sebagai penulis pada artikel ini diharapkan dapat menumbuhkan motivasi peserta didik sehingga mereka lebih antusias mengikuti pembelajaran daring di masa pandemi Covid-19. Berikut ini merupakan hasil angket motivasi yang peneliti berikan kepada peserta didik setelah mereka mengikuti pembelajaran daring menggunakan platform media Google Meeting.

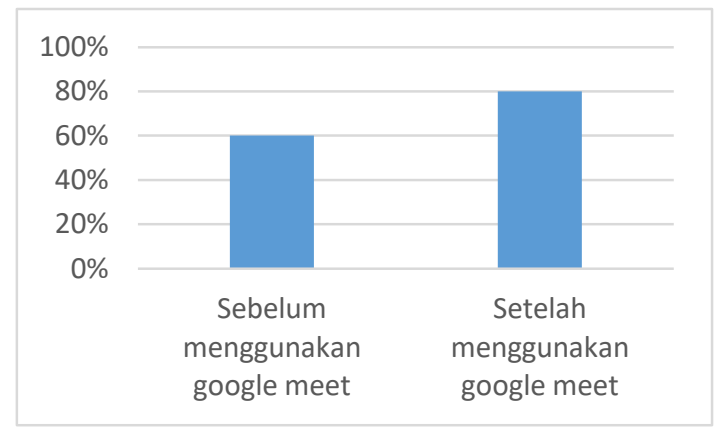

Gambar 1. Hasil Angket Motivasi Peserta Didik dalam Pembelajaran dengan Google Meet 
Gambar 1 menunjukkan bahwa terjadi kenaikan persentase motivasi peserta didik dari $60 \%$ menjadi $80 \%$. Artinya, peserta didik lebih antusias ketika platform media yang digunakan yaitu Google Meeting. Dengan demikian, peserta didik juga lebih termotivasi saat mereka mengerjakan tugas sekolah. Pada saat pembelajaran sebelum menggunakan media Google Meet, guru tidak mengadakan tatap muka virtual. Pembelajaran dengan sistem luring berbasis penugasan, peserta didik diminta mengambil tugas di sekolah dan mengumpulkannya kembali di minggu berikutnya. Setelah menggunakan media Google Meet persentase motivasi peserta didik dalam mengikuti pembelajaran daring menunjukkan persentase $80 \%$ dari keseluruhan jumlah peserta didik. Hal ini menunjukkan peningkatan dari sebelumnya dengan pembelajaran yang belum menggunakan media google meet. Setelah menggunakan media google meet, peserta didik lebih aktif dan termotivasi untuk belajar hal ini ditunjukkan dengan jumlah kehadiran peserta didik saat tatap muka virtual dengan media Google Meet. Hasil observasipun menunjukkan bahwa setelah menggunakan media google meet, peserta didikmenjadi lebih banyak bertanya sehingga berdampak pula pada keterampilan berpikir kritis peserta didik. Hasil wawancara peserta didik juga menunjukkan bahwa kehadiran Google Meet membuat mereka lebih bersemangat dalam mengerjakan tugas sekolah karena mereka bisa dengan leluasa bertanya langsung, bahkan sebagai pengganti interaksi langsung yang selama ini tidak bisa mereka lakukan saat di WhatsApp group. Namun, pelaksanaan pembelajaran daring yang dilakukann juga memiliki berbagai keterbatasan yaitu terkait pembiayaan pelaksanaannya. Orang tua/ wali peserta didik mengatakan bahwa mereka harus mengeluarkan biaya yang cukup mahal untuk membeli kuota data internet. Menurut mereka, pembelajaran daring dalam bentuk video conference menghabiskan banyak kuota data dibandingkan WhatsApp group. Namun, para orang tua/wali juga merasa lebih tenang ketika anak mereka lebih bersemangat dalam mengikuti pembelajaran daring. Walaupun biaya yang dikeluarkan lebih mahal dari biasanya, anak menjadi lebih termotivasi setiap mengikuti pembelajaran. Hal inilah yang membuat orang tua/walipun juga setuju jika pembelajaran daring yang dilakukan melalui Google Meeting. 
Sebagai tindak lanjut, guru akan melakukan variasi dalam pembelajaran jarak jauh, materi pelajaran tertentu adayang diterapkan interkasi langsung synchronous melalui WhatsApp group, dan materi pelajaran tertentu lainnya dilaksanakan secara asynchronous. Hal ini dilakukan dengan memperhatikan tingkat kerumitan dan keabstrakan materi pelajaran. Selain itu, guru juga akan melakukan pengimbasan kepada teman-teman sesama guru khususnya di forum Kelompok Kerja Guru (KKG) tingkat gugus dan kecamatan setelah melaksanakan kegiatan pelaksanaan pembelajaran jarak jauh dengan menggunakan Google Meet. Dengan melakukan tindak lanjut pengimbasan diharapkan dapat memberikan motivasi dan inspirasi terhadap teman sesama guru agar lebih semangat dalam berkreasi dan bersemangat dalam menciptakan pembelajaran yang menarik meskipun di masa pandemi seperti saat ini. Tindak lanjut kegiatan ini sangat penting karena dapat dijadikan bahan refleksi terhadap kegiatan yang sudah dilaksanakan.

\section{Pembahasan}

Peningkatan motivasi peserta didik setelah menggunakan platform media google meet menunjukkan bahwa faktor-faktor terpenting yang harus diperhatikan guru yaitu perhatian, percaya diri guru, pengalaman, mudah menggunakan peralatan, kreatif menggunakan alat, dan menjalin interaksi dengan peserta didik.Materi belajar secara langsung dapat membangun makna, kesan serta memori pada peserta didik(Rohman, Suryawan, \& Priyanto, 2019:121). Divayana, dkk. menyatakan bahwa pembelajaran jarak jauh ini disebut pembelajaran synchronous yang merupakan proses pembelajaran dengan mengadakan interaksi langsung antara peserta didik dengan guru melalui media online dalam waktu yang telah ditetapkan( Divayana, Heryanda, and Suyasa, 2020).

Dengan hadirnya platform media google meet ini, menunjukkan bahwa apapun model pembelajaran yang diterapkan, baik itu pembelajaran daring ataupun luring, Prananda \& Hadiyanto mengungkapkan bahwa motivasi belajar harus selalu ditumbuhkan tidak hanya disebabkan oleh peserta didik, tetapi mungkin dari pendidik/ guru yang tidak berhasil menumbuhkan motivasi tersebut sehingga terjadi penurunan hasil dan minat belajar (Prananda \& Hadiyanto 
2019). Sejalan dengan ini, Tegeh, dkk. menyebut bahwa setiap peserta didik memiliki motivasi belajar yang berbeda, peserta didik yang memiliki motivasi belajar tinggi akan terdorong untuk belajar dan mengerjakan tugas sekolah. Sebaliknya, peserta didik yang memiliki motivasi rendah tidak akan terdorong bahkan malas untuk mengerjakan tugas. Oleh karenanya, motivasi ini juga turut menentukan keaktifan belajar (Tegeh, Pratiwi, \& Simamora 2019). Semakin kuat motivasi yang dimiliki seseorang, akan semakin terlihat kualitas perilaku yang ditampilkannya, baik dalam konteks belajar, bekerja, maupun kehidupan lainnya (Widiastiti \& Sumantri 2020).

Interaksi langsung yang terjadi selama video conference melalui Google Meet juga menandakan bahwa kemampuan berkomunikasi yang meningkat mampu membantu peserta didik dalam pemecahan masalah. Dengan demikian, peserta didik tetap memperoleh pengalaman langsung walaupun pembelajaran yang diterapkan merupakan pembelajaran daring. Seperti yang diungkapkan oleh Hariri dan Yayuk bahwa pembelajaran yang berbasis pengalaman memiliki banyak kelebihan yaitu meningkatkan kesadaran akan rasa percaya diri dan pengalaman tersebut membuat peserta didi berbuat dan berpikir sehingga mampu memberikan pemahaman yang lebih mendalam kepada mereka (Hariri \& Yayuk 2018).

Interaksi yang terjadi secara langsung selama video conference juga menunjukkan bahwa peserta didik tidak kehilangan esensi pokok dalam pembelajaran. Ningsih menyebut pembelajaran online merupakan bentuk pembelajaran jarak jauh yang menghubungkan peserta didik dengan sumber belajarnya yang secara fisik terpisah atau bahkan berjauhan namun dapat saling berkomunikasi, berinteraksi, atau berkolaborasi baik secara langsung/ synchronous atau secara tidak langsung/ asynchronous (Ningsih, 2020). Sadikin dan Hamidah mengungkapkan bahwa pembelajaran onlineyang dilakukan di tengah pandemi Covid-19 memberi dampak positif yaitu mampu menumbuhkan kemandirian belajar peserta didik. Dengan adanya kemandirian belajar ini, mampu memunculkan tanggung jawab dan otonomi dalam belajar (Sadikin \& Hamidah 2020). Interaksi yang terjadi secara langsungpun menjadi menguatkan bahwa pembelajaran jarak jauh yang dilakukan selama masa pandemi covid-19 sangat selaras dengan 
pembelajaran abad ke-21. Seperti yang diungkapkan oleh Hafriyani, bahwa konteks pembelajaran abad ke-21 dikenal dengan 4C memiliki 4 kompetensi yang harus dikuasaisiswa nantinya, yaitu: komunikasi, kolaborasi, berpikir kritis, dan pemecahan masalah; dan mencipta (Harfiyani, 2018). Dengan adanya interaksi yang terjadi secara langsung selama video conference Google Meet, baik guru maupun peserta didik dapat menyamakan kepahaman mereka dalam suatu topik tertentu. Seperti yang ditemukan Didin, dkk. bahwa interaksi langsung atau dikenal dengan istilah synchronous memberi keunggulan bagi pendidik yaitu usaha mental peserta didik lebih besar saat pembelajaran daring secara synchronous (Didin, Mardiono \& Yanuarso 2020). Hal inilah yang dapat mendorong peserta didik untuk tetap fokus saat mengikuti pembelajaran daring.

Hasil penelitian juga menunjukkan bahwa kegiatan penggunaan media google meet meningkatkan literasi digital peserta didik. Di era perkembangan teknologi seperti sekarang peserta didik harus diajarkan berbagai macam teknologi sehingga mereka melek teknologi dan tidak gagap dalam pengoperasiannya. Penggunaan handphone android dan berbagai macam teknologi yang digunakan, menandakan bahwa pembelajaran jarak jauh selama masa pandemi Covid-19 mempercepat arus revolus industri 4.0. Bahkan, pembelajaran jarak jauh yang diterapkanpun mendukung keterlaksanaan pembelajaran abad 21. Seperti yang diungkapkan oleh Martini bahwa pembelajaran abad 21 mengintegrasikan antara kemampuan literasi, keterampilan, dan sikap serta penguasaan terhadap teknologi (Martini, 2018). Fajri menambahkan bahwa pembelajaran abad ke-21 merupakan representasi dari pengalaman berharga dari siswa ketika dirinya akan menghadapi kenyataan pada masa yang akan dating (Fajri, 2017).

Namun, pembelajaran daring yang dilaksanakan selama pandemi covid-19 pun juga tak lepas dari berbagai tantangan yang dihadapi. Seperti, lokasi peserta didik dan guru yang terpisah menyebabkan guru tidak dapat mengawasi secara langsung kegiatan peserta didik selama proses pembelajaran berlangsung. Oleh karenanya, menurut Fahmi dalam pelaksanaan pembelajaran online kesiapan pendidik menjadi fokus tersendiri sehingga pendidik atau guru dapat dengan cepat menyesuaikan 
metode penyampaian materi dan konten pelajaran (Fahmi, 2020). Dengan begitu, reaksi peserta didik dan seluruh kegiatannya selama proses berlangsung dapat dikendalikan oleh guru.

Sehubungan dengan penggunaan media google meet, Setiawan juga menyebut bahwa pembelajaran jarak jauh memberi banyak manfaat diantaranya: dapat memperluas akses pendidikan untuk masyarakat umum dan bisnis karena struktur penjadwalan yang fleksibel mengurangi efek dari banyak kendala waktu dan tempat, penyerahan beberapa kegiatan di luar lokasi mengurangi kendala kapasitas kelembagaan yang timbul darikebutuhan bangunan infrastruktur, serta terdapat potensi untuk meningkatkan akses ke lebih banyak pakar dari beragam latar belakang geografis, sosial, budaya, ekonomi, dan pengalaman. Namun, pembelajaran jarak jauh juga memiliki kekurangan antara lain: hambatan untuk pembelajaran efektif seperti gangguan rumah tangga dan teknologi yang tidak dapat diandalkan, interaksi yang tidak memadai antara siswa dan pengajar, serta kebutuhan untuk pengalaman yang lebih banyak (Setiawan, 2020a). Penelitian Rachmawati juga menemukan bahwa aspek paling memberatkan dilakukan pembelajaran online salama pandemi Covid-19 ini adalah masalah jaringan yang berkaitan dengan sinyal dan kuota paket data. $40 \%$ mahasiswa menyatakan bahwa aspek ini dirasa tidak sesuai dengan yang diharapkan dan memberatkan (Rachmawati et al., 2020). Namun, peningkatan motivasi yang terjadi pada penelitian ini menunjukkan bahwa proses interaksi langsung yang cukup bagus menandakan proses belajar yang dapat membawa peserta didik menangkap isi dan pesan selama prosesnya sehingga ranah kemampuan merekapun terlibat seperti ranah kognitif, afektif, dan psikomotor (Cahyaningsih, 2018).

Peningkatan motivasi yang terjadi setelah peserta didik dan guru menggunakan platform media google meet juga menunjukkan secara nyata hakikat belajar yang sesungguhnya. Sulfemi mengemukakan poin penting pada proses pembelajaran yaitu guru yang mampu menciptakan lingkungan yang menarik dan bermakna sehingga menjadikan peserta didik terlibat aktif (Sulfemi, 2019b). Sejalan dengan hal ini, Lawe menemukan bahwa keterlibatan aktif siswa dipercaya mampu menciptakan rasa ingin tahu 
siswa sehingga siswa tertarik untuk mempelajari materiyang akan disampaikan oleh guru (Lawe 2018). Berbagai macam reaksi peserta didik selama proses pembelajaran menggunakan platform media Google Meet selaras dengan karakteristik cara belajar usia sekolah dasar. Haji menyebut bahwa peserta didik usia sekolah dasar dapat belajar secara efektif ketika merasa puas dengan situasi yang terjadi (Haji, 2015). Hal ini menunjukkan bahwa stimulus yang diberikan guru sangat menentukan perasaan peserta didik, karena hakikat belajar yang sesungguhnya adalah upaya membentuk stimulus dan respon sebanyak-banyaknya (Nahar, 2016). Rijal menguatkan hal tersebut, menurutnya banyak ditemukan berbagai masalah mengenai hasil belajar siswa dalam mengikuti pembelajaran di kelas. Permasalahan tersebut muncul karena kurangnya keaktifan dari diri siswa sendiri sehingga membuat kondisi kelas menjadi pasif dan rendahnya kemampuan siswa, karena pada umumnya siswa lebih suka menghafal daripada latihan dan analisa (Rijal, 2016).

Peranan penting yang dimainkan motivasi belajar menunjukkan bahwa motivasi belajar merupakan syarat mutlak untuk belajar dan memegangperanan penting dalam memberikan gairah atau semangat dalam belajar. Andriani dan rasto menyebut dalam motivasi terkandung adanya keinginan yang mengaktifkan, menggerakkan, menyalurkan dan mengarahkan sikap sertaperilaku pada individu (Andriani \& Rasto 2019). Setiawan menemukan bahwa setiap komponen motivasi belajar berkorelasi positif dengan kompetensi literasi saintifik. Hasil belajar cenderung rendah ketika motivasi rendah. Motivasi dalam pembelajaran merupakan faktorpenting karena kehadiran pelajar dalam kelas, laboratorium, dan/ atau kunjungan lapangan bukan jaminan bahwa mereka ingin belajar (Setiawan, 2020b).

Sulfemi dan Qodir menyebut motivasi dapat juga dikatakan serangkaian usaha untuk menyediakan kondisi-kondisi tertentu. Jika seseorang mau dan ingin melakukan sesuatu, dan bila ia tidak suka, maka ia akan berusaha untuk meniadakan atau mengelakkan perasaan tidak suka itu (Sulfemi \& Qodir 2017). Jadi motivasi itu dapat dirangsang oleh faktor luar tetapi motivasi itu tumbuh didalam diri seseorang. Peserta didik belajar didorong oleh kekuatan mentalnya. Kekuatan mental itu 
berupa keinginan, perhatian, kemauan, atau cita-cita. Kekuatan tersebut dapat tergolong rendah atau tinggi.

Berkaitan dengan pembelajaran jarak jauh selama pandemi Covid19, hakikat belajar tidak bisa terbatas maknanya hanya karena pandemi. Menurut Sulfemi, belajar sebagai konsep mendapatkan pengetahuan dalam prakteknya banyak dianut. Guru bertindak sebagai pengajar yang berusaha memberikan ilmu pengetahuan sebanyak-banyaknya dan peserta didik giat mengumpulkan dan menerimanya (Sulfemi 2019a). Individu dapat dikatakan belajar jika ia dapat menunjukkan perubahan perilakunya karena hakikat belajar merupakan proses perubahan dalam perilaku (Prananda \& Hadiyanto, 2019). Oleh karenanya, motivasi dan keaktifan peserta didik yang rendah saat hanya menggunakan aplikasi whats app group juga berdampak buruk pada hasil belajar. Seperti yang ditemukan oleh Tegeh, dkk. bahwa secara bersama-sama terdapat hubunganyang signifikan antara motivasi dan keaktifan dengan hasil belajar (Tegeh, Pratiwi, \& Simamora, 2019). Sejalan dengan ini, Yanti, Kuntarto, dan Kurniawan mengemukakan bahwa model pembelajaran perlu dirancang denganbaik agar pengalaman belajar peserta didik berkesan dan dapat mencapai tujuan pembelajaran. Model pembelajaran juga menjadi penting karena digunakan oleh guru sebagai pedoman dalam merencanakan dan melaksanakan kegiatan belajar mengajar (Yanti, Kuntarto, \& Kurniawan, 2020).

Meskipun pandemi Covid-19 telah merugikan seluruh dunia dari seluruh sektor kehidupan. Penerapan pembelajaran daring yang dilakukan selama pandemi Covid-19 memberi banyak dampak positif. Sobri, dkk. menemukan bahwa pembelajaran daring menjadikan peserta didik lebih mandiri belajar dengan kata lain senantiasa tidak tergantung kepada orang lain, menetapkan tujuan belajar, mendiagnosis kebutuhan belajar, memiliki rasa percaya diri dan tanggungjawab serta melakukan evaluasi diri (Sobri, Nursaptini, \& Novitasari, 2020). Namun, strategi pembelajaranpun sangat perlu diperhatikan oleh guru. Kristina, Ulliyanti, dan Syamsiati mengungkapkan bahwa strategi pembelajaran merupakan pola umum mewujudkan proses pembelajaran yang diyakini efektivitasnya untuk 
mencapai tujuan pembelajaran.Paling tidak ada tiga jenis strategi yang berkaitan dengan pembelajaran, yaitu strategi pengorganisasian pembelajaran, strategi penyampaian pembelajaran, strategi pengelolaan pembelajaran (Kristina, Ulliyanti, \& Syamsiati, 2015). Selain itu, model pembelajaran yang diterapkanpun sangat bergantung pada kemampuan guru dalam merencanakan pengalaman belajar yang terbuka serta guru harus mampu memberikan rangsangan dan motivasi yang lebih kepada peserta didik (Haryanti, Suhartono, \& Salimi, 2019).

\section{Penutup}

Berdasarkan hasil penelitian dan pembahasan yang telah dilakukan, maka dapat disimpulkan bahwa penggunaan media Google Meet dapat meningkatkan motivasi belajar peserta didik. Hal ini terbukti dengan adanya peningkatan persantase motivasi belajar dari yang smeula 60\% meningkat menjadi 80\% (lihat Gambar 1). Selain itu, interaksi secara langsung atau disebut pembelajaran daring synchronous pada Google Meet juga meningkatkan kemampuan berkomunikasi yang berguna pada pemecahan masalah terkait tugas ataupun materi pelajaran. Hal inilah yang menjadikan pembelaran daring tetap memberikan pengalaman belajar yang bermakna bagi peserta didik. Dengan demikian, mereka tidak kehilangan esensi pokok dalam pembelajaran meskipun pada masa pandemi yang menerapkan pembelajaran jarak jauh.

\section{Ucapan Terimakasih}

Ucapan terimakasih kami haturkan kepada keluarga besar SD Negeri Minggiran I Kabupaten Kediri yang sudah memberikan tempat dan waktu dalam pelaksanaan penelitian ini.

\section{Daftar Referensi}

Andriani, Rike, and Rasto. (2019). Motivasi Belajar Sebagai Determinan Hasil Belajar Siswa (Learning Motivation as Determinant Student Learning Outcomes). Jurnal Pendidikan Manajemen Perkantoran 4(1): 80-86. 
Cahyaningsih, Ujiati. (2018). Penerapan ModelvPembelajaran Kooperatif Tipe TAI (Team Assisted Individualization) Untuk Meningkatkan Hasil Belajar Siswa Pada Mata Pelajaran Matematika. Jurnal Cakrawala Pendas 4(1): 1-14.

Dewi, Wahyu Aji Fatma. (2020). Dampak COVID-19 Terhadap Implementasi Pembelajaran Daring Di Sekolah Dasar. Edukatif: Jurnal Ilmu Pendidikan 2(1): 55-61.

Didin, Fatin Saffanah, Intan Mardiono, \& Hersa Dwi Yanuarso. (2020). "Analisis Beban Kerja Mental Mahasiswa saat Perkuliahan Online Synchronous dan Asynchronous Menggunakan Metode Rating Scale Mental Effort. Jurnal OPSI 13(1): 49-55.

Divayana, Dewa Gede Hendra, Komang Krisna Heryanda, \& P Wayan Arta Suyasa. (2020). Pemberdayaan Pembelajaran Synchronous dan Asynchronous Berbasis Nilai-Nilai Aneka dalam Upaya Peningkatan Karakter Positif Siswa. In Proceeding Senadimas Undiksha Ke-5, Septemnber 2020, , 307-16.

Emda, Amna. (2017). Kedudukan Motivasi Belajar Siswa dalam Pembelajaran. Lantanida Journal 5(2): 93-196.

Fahmi, Muhammad Hanif. (2020). Komunikasi Synchronous dan Asynchronous dalam E-Learning pada Masa Pandemic Covid-19." Jurnal Nomosleca 6(2): 146-58.

Fajri, Muhammad. (2017). Kemampuan Berpikir Matematis dalam Konteks Abad 21 di Sekolah Dasar. LEMMA (Letters of Mathematics Education) III(2): 1-11.

Fitriyani, Yani, Irfan Fauzi, \& Mia Zultrianti Sari. (2020). Motivasi Belajar Mahasiswa Pada Pembelajaran Daring Selama Pandemik Covid19. Jurnal Kependidikan: Jurnal Hasil Penelitian dan Kajian Kepustakaan di Bidang Pendidikan, Pengajaran, dan Pembelajaran 6(2): 165-75.

Ghufron, M A. (2018). Revolusi Industri 4.0: Tantangan, Peluang dan Solusi Bagi Dunia Pendidikan. In Seminar Nasional dan Diskusi Panel Multidisiplin Hasil Penelitian dan Pengabdian kepada Masyarakat 2018 (Vol. 1, No. 1)., , 332-37.

Haji, Sun. (2015). Pembelajaran Tematik Yang Ideal di SD/MI. MODELING: Jurnal Program Studi PGMI 2(1): 56-69.

Harfiyani, Asri. (2018).Penguatan Pendidikan Karakter melalui Budaya Literasi dalam Konteks Pembelajaran Abad 21 di Sekolah Dasar. In Prosding Seminar dan Diskusi Nasional Pendidikan Dasar 2018, 141-50. 
Hariri, Citra Apriovilita, \& Erna Yayuk. 2018. Penerapan Model Experiential Learning untuk Meningkatkan Pemahaman Materi Cahaya Dan Sifat-Sifatnya Siswa Kelas 5 SD. Scholaria: Jurnal Pendidikan dan Kebudayaan 8(1): 1-15.

Haryanti, Arum, Suhartono, \& Moh Salimi. (2019). Penerapan Model Experiental Learninguntuk Meningkatkan Hasil Belajar IPA Tema Panas dan Perpindahannya di Sekolah Dasar. Jurnal Pijar MIPA 14(1): 18-22.

Hasnidar, Hasnidar, \& Elihami Elihami. (2020). Pengaruh Pembelajaran Contextual Teaching Learningterhadap Hasil Belajar PKn Murid Sekolah Dasar." MAHAGURU: Jurnal Pendidikan Guru Sekolah Dasar 1(1): 42-47.

Kristina, Efi, Endang Ulliyanti, \& Syamsiati. (2015). Peningkatan Hasil Belajar Siswa pada Pembelajaran IPA Menggunakan Media Konkrit di Sekolah Dasar. Jurnal Pendidikan dan Pembelajaran Khatulistiwa 4(12): 1-11.

Lase, Delipiter. (2019). Pendidikan di Era Revolusi Industri 4.0 Education. Jurnal Sunderman 12(2): 28-43.

Lawe, Yosefina Uge. (2018). Pengaruh Model Pembelajaran Berbasis Proyek Berbantuan Lembar Kerja Siswa terhadap Hasil Belajar IPA Siswa SD. Journal of Education Technology 2(1): 26-34.

Martini, Eneng. (2018). Membangun Karakter Generasi Muda melalui Model Pembelajaran Berbasis Kecakapan Abad 21. Jurnal Pancasila dan Kewarganegaraan 3(2): 21-27.

Milles, Matthew B., \& A Michael Huberman. (1992). Analisis Data Kualitatif. eds. Tjetjep Rohendi Rohidi and Mulyarto. Jakarta: Universitas Indonesia Press.

Murziqin, R., Idris, S., Usman, N. Hayati, H., Tabrani ZA. (2020). Epidemiology and psychology in handling the psycho-social problem Covid-19. Opcion, 36(91), 1310-1333. https://produccioncientificaluz.org/index.php/opcion/article/vi ew/32502

Nahar, Novi Irwan. (2016). Penerapan Teori Belajar Behavioristik dalam Proses Pembelajaran. NUSANTARA: Jurnal Ilmu Pengetahuan Sosial 1(1).

Ningsih, Sulia. (2020). Persepsi Mahasiswa terhadap Pembelajaran Daring pada Masa Pandemi Covid-19. JINOTEP (Jurnal Inovasi dan Teknologi Pembelajaran) 7(2): 124-32. 
Prananda, Gingga, \& Hadiyanto. (2019). Korelasi antara Motivasi Belajar dengan Hasil Belajar Siswa dalam Pembelajaran IPA di Sekolah Dasar." Jurnal Basicedu 3(3): 909-15.

Rachmawati, Yuanita et al. (2020). "Studi Eksplorasi Pembelajaran Pendidikan IPA saat Masa Pandemi COVID-19 di UIN Sunan Ampel Surabaya." Indonesian Journal of Science Learning 1(1): 32-36.

Rijal, Syamsur. (2016). Efektivitas Pembelajaran Matematika Siswa melalui Penerapan Teori Belajar Bruner. In Prosiding Seminar Nasional, , 489-95.

Rohman, Aris Abdul, Ace Iwan Suryawan, \& Imam Jahrudin Priyanto. (2019). Penerapan Model Experiential Learning Berbantuan Media Gambar untuk Meningkatkan Kreativitas Kerajinan Tangan Peserta Didik." EDUCARE 17(2): 119-26.

Sadikin, Ali, \& Afreni Hamidah. (2020). Pembelajaran Daring di Tengah Wabah Covid-19. Biodik: Jurnal Imiah Pendidikan Biologi 6(2): 214-24.

Setiawan, Adib Rifqi. (2019a). Literasi Saintifik Berdasarkan Kecerdasan Majemuk dan Motivasi Belajar. Media Penelitian Pendidikan: Jurnal Penelitian dalam Bidang Pendidikan dan Pengajaran 13(2): 126-37.

Setiawan, Adib Rifqi. (2019b). Penggunaan Mabadi 'Asyroh dalam Pembelajaran Biologi untuk Meningkatkan Motivasi dan Hasil Belajar. In Seminar Nasional Biologi 2019 "Inovasi Penelitian Dan Pembelajaran Biologi III (IP2B III) 2019," , 158-64.

Setiawan, Adib Rifqi. (2020a). Lembar Kegiatan Literasi Saintifik untuk Pembelajaran Jarak Jauh Topik Penyakit Coronavirus 2019 (COVID-19). Edukatif: Jurnal Ilmu Pendidikan 2(1): 28-37.

Setiawan, Adib Rifqi. (2020b). Profil Literasi Saintifik Berdasarkan Kecerdasan Majemuk Dan Motivasi Belajar (Scientific Literacy Profile Based on Multiple Intelligences and Learning Motivation).

Sobri, Muhammad, Nursaptini, \& Setiani Novitasari. (2020). Mewujudkan Kemandirian Belajar Melalui Pembelajaran Berbasis Daring di Perguruan Tinggi pada Era Industri 4.0." Jurnal Pendidikan Glasser 4(1): 64-71.

Sugiyono. (2015). Metode Penelitian Kuantitatif Kualitatif dan RED. Bandung: Alfabeta.

Sulfemi, Wahyu Bagja. (2019a). “Hubungan Motivasi Belajar dengan Hasil Belajar IPS di SMP Kabupaten Bogor. Edutecno: Jurnal Pendidikan dan Administrasi Pendidikan 18(106): 1-12. 
Sulfemi, Wahyu Bagja. (2019b). Model Pembelajaran Kooperatif Mind Mapping Berbantu Audio Visual dalam Meningkatkan Minat, Motivasi,dan Hasil Belajar IPS. Jurnal Pendidikan Ilmu Pengetahuan Sosial Indonesia 4(1): 13-19.

Sulfemi, Wahyu Bagja, \& Abdul Qodir. (2017). Hubungan Kurikulum 2013 dengan Motivasi Belajar Peserta Didik di SMK Pelita Ciampea. Edutecno: Jurnal Pendidikan dan Administrasi Pendidikan 17(106):1-12.

Tegeh, I Made, Ni Luh Ariesti Pratiwi, \& Alexander Hamonangan Simamora. (2019). Hubungan Antara Motivasi Belajar dan Keaktifan Belajar dengan Hasil Belajar IPA Siswa Kelas V SD. jurnal IKA 17(2): 150-70.

Widiastiti, Ni Luh Ayu, \& Made Sumantri. (2020). Model Quantum Teaching Berbasis Pendidikan Karakter terhadap Motivasi Belajar IPA." Jurnal Pedagogi dan Pembelajaran 3(2): 303-14.

Yanti, Minanti Tirta, Eko Kuntarto, \& Agung Rimba Kurniawan. (2020). Pemanfaatan Portal Rumah Belajar Kemendikbud sebagai Model Pembelajaran Daring di Sekolah Dasar. Adi Widya: Jurnal pendidikan Dasar 10(1): 61-68. 
